\title{
7 Youth law, policies and their implementation in the Russian Arctic
}

\author{
Aytalina Ivanova, Tatyana Oglezneva and \\ Florian Stammler
}

\section{Introduction}

There is a high demand for youth in the Russian Arctic as the territories making up the region should be strategic drivers of development in the country at large (Fondahl et al. 2020, pp. 195-196). Yet the region is losing population and suffers from a lack of qualified labour. In this chapter our starting point is that a low working-age population remains the most significant problem where development of the Russian Arctic is concerned. PostSoviet state policy has not yet solved this problem. Retaining young people who were born in the region is particularly important for decreasing outmigration (Volgin et al. 2018, pp. 44-45). In this respect, the Russian Arctic has a combination of material and moral incentives for attracting and retaining youth. These include a fairly well-developed system of cities and large urban settlements which have survived from the Soviet period of northern development (Zamiatina 2020). On the other hand, the Soviet industrial heritage is not enough to keep young qualified people living in Arctic cities (see Bolotova, this volume).

This chapter first outlines the regulatory framework for Russian youth policy in the Arctic in light of the current demographic, economic and social challenges facing the region. We adhere to the administrative and legal structure of the Russian Federation, looking first at federal and then at regional laws and policies. An analytical section on implementation then draws on case studies in the cities of Neryungri (Yakutia), Novy Urengoy (Yamal), and Kirovsk/Apatity (Murmansk Region). Based on document analysis and onsite fieldwork visits, we analyse the local implementation of particular policies and programmes and their acceptance among local young people.

Public debates and discussions about policy and regulation reveal that there are two main tendencies when it comes to assessing human capital in the Arctic: one group in the debate maintains that Russian Arctic cities are overpopulated as a legacy of Soviet settlement policies (Hill and Gaddy 2003); the other, whose argument we support, contends that one cannot develop the Arctic without people and that incentives should be created for people to stay or come to the North (Parente et al. 2012 and in this volume: Adams et al.; Bolotova; Komu and Adams; 
Simakova et al.). Since the end of the Soviet Union, the Russian Arctic has experienced a significant outflow of population, although this has not occurred evenly across all parts of the region (Heleniak 2009). For example, over the past 20 years the population in the 13 Arctic municipalities of the Republic of Sakha (Yakutia) has decreased by more than half, from 148,000 to 68,000 persons. In comparison, the decline in the permanent population of the Russian Arctic at large has been less drastic, with a decrease from 2,400,000 to 2,371,000 recorded for 2014 and 2017 (Mikhailovskaia 2018a).

Many regions in the Russian Arctic require a larger labour force. The need for young trained specialists in the North annually is 25,000 people (Volgin et al. 2018, p. 46). The outflow of graduates, the region's limited educational opportunities and the need to train young specialists to meet the requirements of the companies working in the Arctic are acute concerns. Accordingly, there is an urgent need to create a set of measures to attract and retain specialists from other regions of Russia. In recent years, this question has received a great deal of attention among various stakeholders in Russia, which can be seen from an increase in the range of conferences organized on this topic. Participants in these forums have come up with important suggestions and avenues for development, several of which are illustrated below.

One recent conference resolution stated:

[in order] to provide the Arctic with young professional personnel and to retain the population of the northern regions, it is currently important to determine the life strategies of modern youth in the Arctic and to create suitable conditions for their professional and social self-realization.

(Assotsiatsiia Poliarnikov 2018, p. 5)

Many activists and decision-makers at the nationwide meeting agreed that the first and main condition for the consolidation of youth in the Arctic is to improve infrastructure, transport and further cultural and social development. One idea was to launch a broad information campaign on the benefits of living in the North.

Another recent Arctic meeting in Russia featured a special "day of youth" (Assotsiatsiia Poliarnikov 2019), a forum where young people from the Arctic shared their experiences of participating in various Russia-wide youth competitions. This form of collective action is popular throughout the country and provides people with avenues for realizing their dreams and plans. The occasions offer young people the opportunity to make new contacts, as well as inspiration in the form of new ideas for solving problems of their home, which many call "malaya rodina" ("small homeland", meaning one's specific place of birth or living, as distinct from Russia as a whole). According to the Russian Ministry for Far Eastern and Arctic Development, business in the Arctic must be stimulated by preferential credit rates for the import of goods as a means to offset the increased expenses of delivering supplies to the North. The new law on business support for the Arctic embodies this approach (Russian Federation 2020; Trutnev and Kozlov 2020). 
At yet another meeting in March 2017 (Dolgova et al. 2017), young professionals came up with their own proposals for Arctic development. They considered that the key goal of the Arctic Development Strategy should be to ensure human wellbeing in a stable and safe Arctic. Furthermore, they emphasized that any youth strategy for the Arctic should prioritize a balance between intensive innovative socio-economic development and sustainable development.

Notwithstanding such numerous meetings and an increased interest in the Arctic, we are of the view that Russian youth policy does not yet take into account the specifics of the northern territories and that the relevant laws in the field of youth policy are still insufficiently integrated (Federative Council 2009, p. 3).

To promote the interests of young people, a national Youth Chamber was established in 2001 under the State Duma, later, in 2011, becoming the Russian Youth Parliament (Mikhailovskaia 2018b). Thereafter, Arctic regions duplicated this system, establishing regional youth parliaments of their own. For example, in our case regions, the youth chambers became youth parliaments in 2016 in Yamal (Zakonodatel'noe Sobranie YNAO 2016), in 2017 in Murmansk Region (Severpost 2017) and in 2019 in Yakutia (Press-sluzhba Il Tumena 2019). Such forums have started working within the last ten years in almost all Arctic regions. The main goal of the new platform is to improve dialogue between the Arctic regions of the Russian Federation, promote regulation of the rights and legitimate interests of young people in those regions, develop projects aimed at stopping the outflow of young people and from the Arctic and create a positive image of Russia's activities there (Mikhailovskaia 2018b). Other aims include systematic work to highlight the possibilities of a decent life, work and self-realization for students in the harsh conditions of the North, for which young people need to be made aware of opportunities for professional growth and development. This mechanism makes it is possible to develop a new strategy, different from that practiced in Soviet times, to attract young people to live and work in the Arctic.

\section{Russia's Arctic youth policy}

In the absence of a Youth Act, youth in Russia are covered by a system of social obligations and guarantees that applies across the entire country. These are outlined in the Russian youth policy programme (Government of the Russian Federation 2014), as well as different government-funded programmes, for example the one focusing on housing for young families (Government of the Russian Federation 2016). However, as these programmes do not consider the particular conditions in the North, another set of privileges has been established for all Russian citizens and even foreigners with the right to work and reside in the Arctic (Konsul'tantPlius 2017). This is the so-called "regional coefficient", a bonus added to wages that are paid in areas officially belonging to the Far North of Russia. Such salary top-ups 
for people working in the North were first introduced during the Soviet Union after Stalin. The system is based on the principle that the harsher the climatic conditions of the area are for work, the higher the top-up should be (State archive Murmansk 2012). It continues to play an important role for the demography of the Russian North as a whole.

Russia is organized as a federal state that is divided into different regional administrative entities (known as subekty), which have the right to pass their own legislation in areas of regional relevance provided this does not conflict with federal law. Given this competence, seven Arctic units of the Russian Federation have passed legislation entitling all young employees of state institutions who are under 30 years of age to receive the full salary bonus from the first day of work. The regions are the Republic of Sakha (Yakutia), the Republic of Komi, the Krasnoyarsk Territory, the Arkhangelsk and Murmansk Regions and the Yamal-Nenets and Chukotka Autonomous Districts. Youth law in general is a field where Russian regions have seen fit to exercise their legal competence: even though there is no such law at the federal level, all of the nine Arctic regions of the Russian Federation have enacted their own youth legislation regulating social relations in the field of youth policy, albeit with varying degrees of detail and effectiveness. These regions are the Republics of Karelia, Sakha (Yakutia), and Komi, the Krasnoyarsk Territory, the Arkhangelsk and Murmansk Regions and the Yamal-Nenets, Nenets and Chukotka Autonomous Districts. Seven of the Arctic regions (the exceptions being Murmansk and Chukotka) have enacted laws on youth and youth policy, some of which are described in detail below. These laws determine the general objectives and principles of youth policy in the respective regions. The stated goals include the following:

- establishment of methods of informational, scientific, methodological and personnel support in the field of youth policy;

- organizational and legal support of the main directions of youth policy;

- organization of youth policy management; development of mechanisms strengthening legal regulation and the uniformity of youth policy at the regional and municipal levels;

- youth policy financing;

- measures to support youth in the field of education;

- vocational guidance;

- labour and employment assistance;

- support of entrepreneurship; and

- support with housing for young families.

Several specific examples from the regions will serve to show the orientation of such youth laws.

In the Republic of Sakha (Yakutia) (Il Tumen 2018), organizations creating additional youth jobs may be granted tax benefits. Employers owned fully or partially by the regional authorities are required to create jobs for young professionals permanently residing in the republic, specifically persons up to 
30 years of age with secondary vocational or higher education. Companies with fewer than 100 employees need to provide at least 1 per cent (meaning a minimum one job) of such jobs. Moreover, at the birth of their first child (or adoption of a child under the age of three months), young parents in the republic have the right to receive a one-time allowance for the purchase of the child's first needs and food (today RUB 7048) (Ob okhrane sem'i, materinstva, ottsovstva i detstva 2008).

In the Yamal-Nenets Autonomous District (hereafter YNAO) (O molodezhnoi politike v Iamalo-Nenetskom avtonomnom okruge 2009), young specialists whose first principal place of employment falls under an employment contract in state and municipal institutions related to youth are provided with a one-time payment, as well as a monthly allowance paid for the first three years from the day of employment, while they are under the age of 31 years.

In all Russian regions, housing is considered a key area in which youth need state support. This being the case, in addition to the above-mentioned federal programme, regional governments develop and implement measures for subsidizing interest rates on housing loans, which attracts young citizens to work in the public sector in state and municipal institutions.

While this shows a significant "niche of agency" (Fondahl et al. 2019) for regions in the absence of applicable federal law, the main problem related to implementation is the lack of funding for the measures adopted. Furthermore, the conditions in the Arctic impose specific financial burdens on the regions stemming from the climatic and transport conditions, such as the difficulty of delivering fuel and food to remote areas within what is a very narrow seasonal window. In short, the public sector is more expensive to maintain in the Arctic region, whereby the degree to which Arctic territories can be developed depends greatly on budgetary security and on financial assistance from the federal treasury.

Article 41 of the Russian Labour Code gives businesses the right to take on increased financial obligations, for example in a collective agreement. Taking into account its financial and economic situation, a company can, for example, pay benefits to employees, create more favourable working conditions or make agreements offering terms going beyond the minimum established by law.

One such example is the Russian State Railway Company (RZD), which, in 2018, introduced amendments to the corporate salary system allowing the managers of the different regional railway divisions to switch over to a more favourable system of allocating salary top-ups to youth in the North (Truntseva 2018). The Northern and the East Siberian Division of RZD have opted for this system so far. The Northern Division considers the abolition of seniority as a prerequisite for obtaining the northern salary top-ups to be good motivation for young professionals. For example, a young person working in the Arkhangelsk subdivision of the northern railways will receive a bonus of 50 per cent on top of the base salary, just as his or her senior colleagues do. In the Yamal-Nenets Autonomous District, this figure is 80 per cent. In other words, a railway worker there is paid 80 per cent more for the 
same work than his or her colleague working in a region without northern salary top-ups. The introduction of such regulations has increased the competitiveness of railroad workers' wages in regional labour markets. This can stimulate an influx of young workers and specialists to the Russian Arctic. However, since the regulation is recent (2018), its effectiveness cannot yet be demonstrated in numerical terms.

Such measures show that not only regional authorities in Russia but also large corporate actors have opportunities to influence youth policy and regulation in the Arctic to their own advantage, creating incentives for youth. This indicates, as we have argued elsewhere (Stammler and Ivanova 2016; Fondahl et al. 2019), that there is more agency in Russia's Arctic regions than the image of a strong centralised federal state with a strong president might suggest.

\section{Implementation of youth policy in Russian Arctic single- industry towns}

In this section we show that opportunities to influence conditions of wellbeing for youth do not stop at the regional level in the Russian Arctic; cities and municipalities also have certain legal competences at their disposal. According to federal law, municipalities are responsible for working with children and youth (Russian Federation 2019). For the local governments of single-industry towns, this means an additional budgetary burden if they are to retain and attract youth. In our research project, we studied how four cities in this category used their competences: Neryungri (Republic of Sakha (Yakutia)), Novy Urengoy (Yamal-Nenets Autonomous District), Apatity and Kirovsk (Murmansk Region), thus adding to the ethnographic depth of other chapters in this volume focusing on the same cities (Bolotova, Simakova et al.).

\section{Neryungri-_You decide what your city looks like"}

The municipality of Neryungri adopted a five-year programme for implementing youth policy (2017-2021) (Administratsiia Neriungrinskogo Raiona 2016), the main aim of which is to improve conditions and guarantees for the economic and social wellbeing of young people. Neryungri's population, like that of many other single-industry towns in the northern and Arctic territories, is still decreasing slightly each year. In the first ten years of its existence, the city grew very rapidly, reaching 100,000 inhabitants in 1985. After the collapse of the Soviet Union, about half the population of the city left, but recently the decrease has slowed: between 2010 and 2019, the population of the city decreased from 61,747 people to 56,888 people. However, the proportion of young people in town is quite large (as much as 30 per cent), making the youth policy programme significant. The programme comprises the following measures:

- "Support for youth initiatives and the provision of socio-psychological support"; 
- "Patriotic education of youth"; and

- "Support for socially oriented non-profit organizations".

Another municipal five-year programme focuses on providing housing to young families, defined as those in which the spouses are under 35 years old. This is co-financed by all three levels of the Russian state (federal, regional, municipal) as well as non-state sources. At the beginning of 2016, 25 young families were registered for getting support from the programme. The five-year funding for this programme would provide the equivalent of approximately twelve apartments in Neryungri (Administratsiia Neriungrinskogo Raiona 2018a). If the funds are used for financing a mortgage or bank loan, more families can improve their housing situation with that money. An additional support measure has been in effect in the Neryungri district for pupils and students from low-income families (including large families) that pays compensation to cover the cost of travelling to a place of study within the district (Administratsiia Neriungrinskogo Raiona 2018c, 2018b).

Since Neryungri is a single-industry town, the main company in the city can also significantly influence the attractiveness of the city for its young inhabitants. Especially where municipal budgets are small, various forms of public-private co-financing are one way of increasing the effectiveness of youth programmes. The main coal mining company in Neryungri, Yakutugol, participates in the Yakutia-wide programme "Local personnel in the industry". Close cooperation has been established with the governments and employment centres of the rural municipalities. At career counselling meetings, company employees can inform local residents about working conditions, requirements for applicants, the level of salaries, as well as social guarantees and opportunities for professional self-realization.

In practice, while these measures have not stopped outmigration, we can still state, based on our fieldwork, that they have contributed to slowing the downward development in the city and the atmosphere of decay that Bolotova (this volume) identified in shrinking cities. Several examples will serve to demonstrate this: While Neryungri remains a single-industry town, its economic profile has been diversified and additional work opportunities for young people have been created. One would think that building housing is not a priority in a town where the population has shrunk by more than 30,000 people from its peak. However, fieldwork conversations show that the old Soviet housing is not attractive enough for young people, with some houses being dilapidated wooden barracks and others ill-maintained 1970s Sovietstyle apartments. In our focus group discussion with young employees of both major coal mining companies, housing was among the most important topics mentioned in connection with their sense of a good life. In 2017, 400 new apartments were built by the municipality; during our fieldwork, we witnessed young people moving into these buildings (Figure 7.1).

Higher and other post-secondary educational opportunities are another important "plus" for this northern town, without which the outmigration 


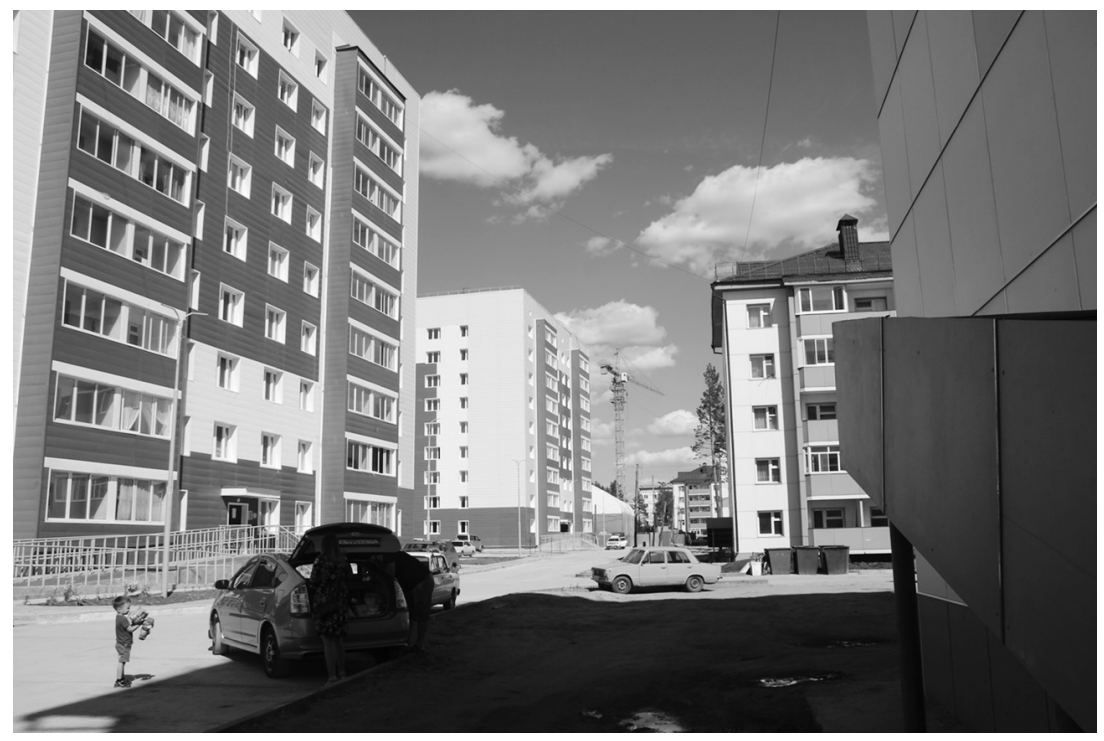

Figure 7.1 Young family moving in one of the new apartments in Neryungri, Churapchinskaia Street.

(Photo: F. Stammler, 2018)

might have been higher. These include the programmes at a technical institute which is a branch of Yakutsk North Eastern Federal University and educates specialists in high demand in town. According to Director Pavlov (2018), all graduates in the mining-related professions can find a job in town if they want. The institute also offers degrees in philology and economics. On a more vocationally oriented level, South Yakutian college educates technical specialists, who are also in high demand in the town. Retaining young educated people in town also creates a demand for more facilities to promote social wellbeing. The city tries to meet this need with various initiatives increasing a positive atmosphere, one being a citizen participation contest geared to upgrading public spaces such as parks, walkways and bus stops, with the slogan "you decide how your city looks like".

In civil society, churches are important actors, offering as they do activities for young families. One opportunity of note in Neryungri is the youth activity of the evangelical church, which has a very active youth pastor, Alexandr Proshchalgin. In his "laboratory of applied social technologies", as he calls it, he organizes a variety of youth activities. These include extreme sports activities, outdoor bonding between fathers and sons, motorsport activities, counselling for young families, as well as drug and alcohol prevention measures such as life orientation through lectures and activities. He counted that more than 1500 young people between the ages of 16 and 20 have already taken part in such measures, and is proud to announce that some have gone from being on the verge of a life of crime to becoming millionaires (Proshchalgin 2018). 


\section{Novy Urengoy — how much rootedness can gas money buy?}

The city of Novy Urengoy has different starting conditions than most other Russian industrial towns. It advertises itself as the "gas capital of Russia", as the discovery of two of Gazprom's biggest deposits in the vicinity were the reason for its establishment. The population has increased slightly in the last ten years, from 104,000 to 118,000 inhabitants (Rosstat 2020). In this singleindustry town reliant on gas revenues, making money has been an important goal among many inhabitants since Soviet times (Stammler 2010). An analysis of the situation of the town's youth shows that despite increased non-monetary incentives to make life there attractive in recent years, young people's tendency to focus solely on increased material wellbeing has remained unchanged since Soviet times: the idea is to make enough money while living in Novy Urengoy and then relocate to a more comfortable place. Thus, even decades after the end of the Soviet Union, the city retains the image of a transient residence and this cannot be ascribed solely to its Soviet heritage. As previous research has shown, even though "The City Became the Homeland for its Inhabitants, (...) Nobody is Planning to die here" (Stammler 2010, p. 33).

The municipal programme "Children and Youth. Development of Civil Society 2014-2020" aims at creating legal, economic and organizational conditions for young people's personal development and support for public youth associations in order to increase their social wellbeing (Administratsiia goroda Novyi Urengoi 2017). The programme is divided into two sections, "Social and personal development of youth and children's travelling for recreation during the holidays" and "Support of socially oriented non-profit organizations", with the latter able to get staff salaries from programme funds. The programme is administered by the Department for Youth and Public Affairs of the Administration of the City of Novy Urengoy. Several institutions targeting different groups of youth are financed from the department's budget. For example, the youth centre "Nord" has a focus on motorsports (go-karts, motocross bikes and snowmobiles) and organizes survival training outdoors, partially combined with what the organizers call "military patriotic education". While participants learn how to survive outdoors, they also learn how to assemble a Kalashnikov automatic rifle, get to test military gear and learn about the Russian army. It is worth noting that girls also actively take part in what is usually a male-dominated sphere. Some make it to regional or Russia-wide competitions, for example, in motocross or snowmobile racing. The city finances the building used by the centre, the salaries of the staff and some basic equipment. Members of "Nord" contribute by buying their own equipment, which they bring to the centre. In the workshops young people also learn to fix their motorbikes, go-karts and snowmobiles with instruction from trainers paid by the city. The centre has more than 200 active members, but many of the young people come with their parents (Vorobiev 2019) (Figure 7.2).

Another youth centre, "Optimist", is more oriented towards indoor activities with youth. It provides space for youth to organize, engage in intellectual 


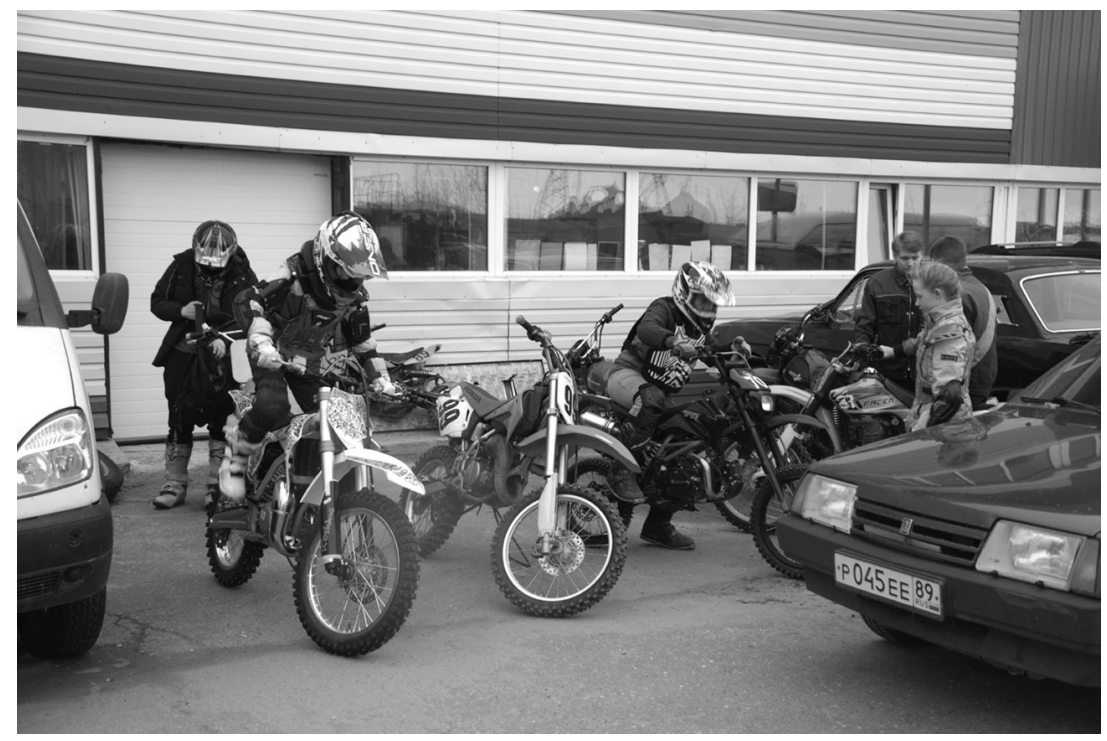

Figure 7.2 Novyi Urengoy youth leaving for motocross behind the workshop of the municipal club "Nord".

(Photo: F. Stammler, 2019)

games and role-play games, invent their own programmes, develop business ideas or just hang out. The municipality also finances the building and basic staff, while the activities are often directed by volunteers. Ideas seen at the centre were born out of practice, some being public service publications such as "How to walk your dog in a clean way in town" or "How to live a healthy lifestyle", one other a project titled "Veterans live next door", in which the participants went to record the life histories of war veterans. In addition, Novy Urengoy has two state-of-the-art sports centres that are as wellequipped and well-staffed as one may find in Moscow, New York or Paris. Co-financed by Gazprom and the municipality, any sports training for youth is free there, and possibilities to develop one's sports ambitions are plentiful. The most talented and ambitious youth may end up as professionals either in the Gazprom-owned sports clubs or elsewhere, although the orientation of the centre is towards promoting sport among the population at large (Reimer 2019). Thus, local youth have more to choose from in comparison to many other cities, yet this has not changed the spirit of transience that the city inherited from its Soviet past.

\section{Kirovsk — the North is for living}

Our field site in Murmansk Region was the phosphate mining city of Kirovsk, which is on the list of Russian single-industry towns "with the most difficult socio-economic situation". The population decreased from 43,526 to 26,206 between 1989 and 2019 (Rosstat 2020). In its programme, the municipality 
groups youth policy together with education, culture and sports. In the most recent programme, the desired social and economic results include the improvement of social services as a whole in Kirovsk, which should translate into an increased level of satisfaction among the residents with municipal social services. Another stated aim is improving conditions for the self-realization and adaptation of young people in society. However, of the total budget of the programme, some RUB 968,000,000 (EUR 11,000,000), only RUB 674,000 (EUR 7500) was allocated directly for the implementation of youth policy, in particular youth initiatives and projects for the first three years. During meetings in Kirovsk, we found that young people do not participate much in the implementation of urban projects financed through the programme. The lack of youth centres, places of leisure, support for young entrepreneurship and attractive employment other than with the principal mining company may make young people think quite seriously of moving to bigger cities. On the other hand, youth in Kirovsk are active in areas not connected with any municipal or company programmes. There are several youth centres or associations established by young people themselves, examples being the alternative cinema club "Art powder", a number of self-organized groups for extreme winter sports and survival training in the forest, as well as a recycling initiative, some of which are described in more detail in Bolotova's chapter (Bolotova, this volume).

Another particular feature of Kirovsk is geographical: of all the cities in our research, Kirovsk is the one which is best connected to Moscow and St. Petersburg, and another big city, Murmansk, is only $200 \mathrm{~km}$ away, a threehour drive. Moreover, several other industrial cities are within an hour's drive, such as Monchegorsk, Olenegorsk, Polyarnye Zory and Kandalaksha. Perhaps most importantly, Kirovsk has a younger and bigger twin city, Apatity, just half an hour's drive away; Apatity has twice the population of Kirovsk and more youth-related activities as well. Apatity also has a youth centre funded by the municipality and that employs seventeen people. A municipal programme called "Involving youth in social practice" aims at improving the socio-economic and organizational conditions for the successful integration of youth into society. The focus is on involving youth more in social activities, promoting career guidance and career aspirations of youth and providing assistance for developing their creative potential. Among the measures contributing to this last goal are bonuses and financial incentives for especially talented children.

Some of the more active youth commute between Kirovsk and Apatity. There is a volunteer association which has 311 registered young people as members. A lot of the volunteers' activities take place in both Kirovsk and Apatity, with these including volunteer "cleaning-up Saturdays" (subbotniki), a video festival of extreme sports and youth cinema. During fieldwork in 2019 we learned that some of these activities are co-funded by the mining company, while others are crowd-funded. On balance, the impression from talking to youth active in the cities is that there are many more opportunities where young people can test themselves and realize themselves than merely looking at municipal programmes might suggest. 
The principal enterprise of Kirovsk and Apatity is Apatit, part of the PhosAgro company, one of the world's largest producers of phosphate for mineral fertilizers. The company is of crucial importance to both cities. The social orientation of the company has a strong focus on its young employees. For example, the company's youth council takes part in improving the life of young people and has 350 members. In addition to supporting its own employees, the company has financed or co-financed the repair of infrastructure of importance to young people, such as the Kirovsk swimming pool, the palace of culture, sports centres and the downhill skiing resort "BigWood".

Kirovsk is a focal point in the regional identity-making programme, which features the slogan "na severe - zhit" ("the North is for living"). The young governor of the Murmansk Region is said to have coined the slogan himself (Novosti Murmanska 2020), effectively focusing attention on people's wellbeing as a principal goal of regional policies. The Kirovsk ski resort and the snow art attraction snezhnaya derevnya ("snow village") have adopted the slogan to promote the city as a tourist destination. In the season 2019/2020, the slogan appeared on souvenirs such as t-shirts, on ice art and on posters at the ski resort (Figure 7.3).

On the one hand, this advertising could be seen as a cheap PR campaign to direct attention away from real problems, as suggested in the analysis of the oppositional newspaper Novaya Gazeta (Britskaia 2019). On the other hand, during fieldwork in the spring 2020 we noticed among young people in

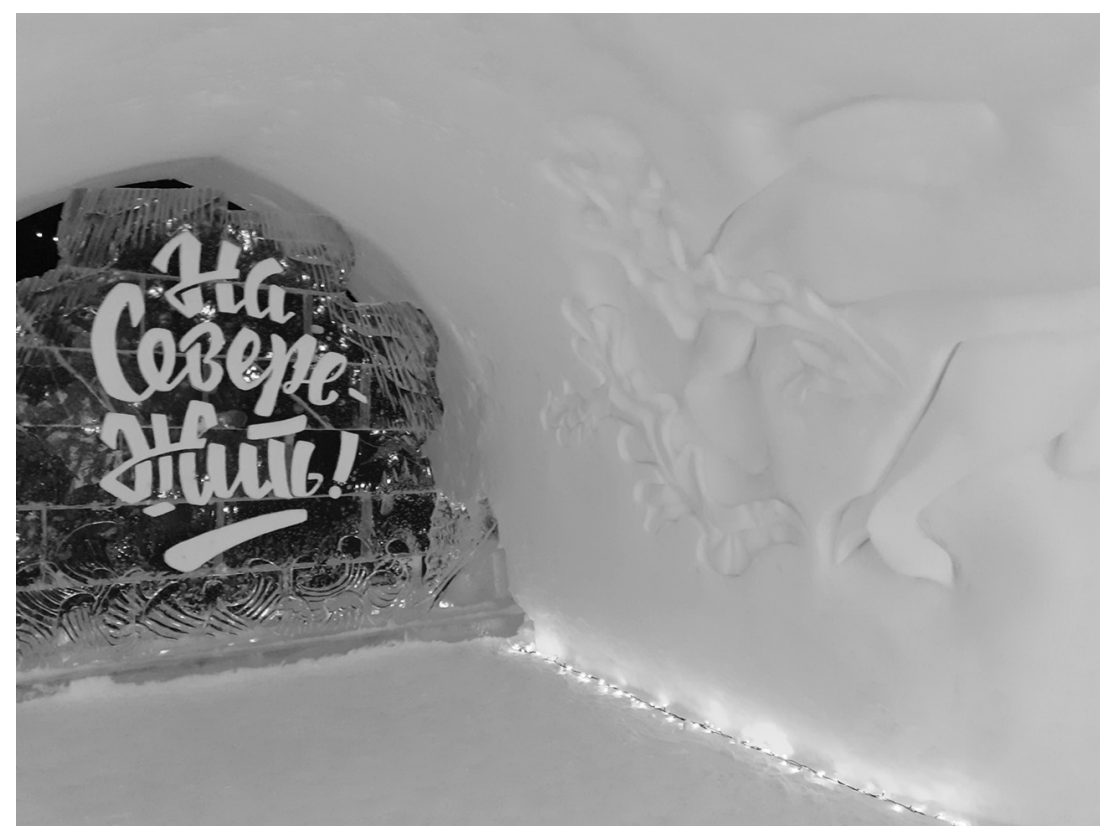

Figure 7.3 "The North is for living" — slogan for northern wellbeing by the Murmansk Governor, adopted in the ice art of the Kirovsk snow village.

(Photo: F. Stammler, 2019) 
Kirovsk a certain sense of pride in and identification with this slogan. Indeed, it is by far not only tourists from outside the region who buy the $t$-shirts with the slogan; locals wear them too. In an article on place identity in mining towns in Mexico, Harner (2001, p. 660) underlines that "place identity arises when the shared beliefs about place meaning for the majority match the ideological beliefs of those in power". Young people in Kirovsk endorsing the governor's slogan about a place identity attached to the North may be such an example.

\section{The involvement of industry in educating qualified youth for industrial cities}

As we have shown in the beginning, the Russian Arctic needs qualified personnel for furthering development. In this sphere, big enterprises working in the region play an important role in educating students for future work in the single-industry towns. In contemporary Russia, that is, after the end of the Soviet Union, positive effects have been noted in those cities where corporate involvement in education is practiced as part of companies' social policies and corporate social responsibility (Romanenko 2019 see also Adams et al., this volume). Companies can play an important role in better tailoring education to the needs of the labour market, by both materially equipping educational institutions and by arranging practice-oriented training for youth by company employees. In our three case cities, the personnel managers of all the companies have mentioned the advantages of educating local people, as they do not require additional adaptation to the harsh Arctic climate and working conditions. We argue that the extent to which company-public partnerships in educating youth are successful has an important influence on the attractiveness of Arctic single-industry towns as places to live for young people. Several examples from our three case sites show how companies engage in education; we witnessed this engagement during field visits to the respective companies and educational institutions.

Kirovsk and Murmansk Regions have paid attention to the seamless integration of the education offered by schools, colleges and industry. The main company in town, PhosAgro Apatit, sponsors a specialized mining orientation already in secondary school to raise interest in local children for the mining sector (for more details see Bolotova, this volume). Murmansk Arctic State University (MASU) now includes a Kola branch office in Apatity, previously part of Petrozavodsk State University. Moreover, the Khibiny Technical College in Kirovsk, previously affiliated with the National Mineral Resources University, has also become part of MASU. In the aforementioned college, PhosAgro Apatit participates both intellectually and materially in the education process: the mining classes are equipped with simulators and technical stations that are almost identical to those used in the company. Students learn the entire process of extraction and enrichment of Apatit phosphate. Some of the teachers are employees of PhosAgro Apatit and give students the benefit of their own work experience. Most of the mandatory 
work practice undertaken by the students takes place at the company premises in Kirovsk, and most of those who want to work at PhosAgro after graduation find employment there. At a focus group discussion with students of the college, female pupils especially valued the fact that there are now more subjects to choose from than mining. Since 2018, the college has offered hospitality as a profession in a four-year education programme. During a visit to the college the students suggested demonstrating to us in a role play how they learn to work with tourists in the hospitality business: they set up a hotel reception area, arranged a coffee service and provided advice on excursions and help with other questions typically asked by tourists. Bolotova (this volume) shows the importance of such diversification in the education sector.

This degree of partnership is absent in Novy Urengoy. Gazprom established its own technical educational institution, called Gazprom Tekhnikum Novy Urengoy. However, the option of becoming affiliated with a university was ruled out, as the entire YNAO does not have a single university on its territory, and earlier branch offices of larger universities were closed due to poor quality. Gazprom Tekhnikum is part of the personnel division of Gazprom Moscow and educates specialists in seven areas, with a total of 1000 students being trained at the institution. Economics was discontinued as a major subject, so that today all of the education is gas-oriented. It starts already in the tenth grade and continues for another three years. Once a student enters the Gazprom system, the company can follow his or her professional path anywhere in the country and employment options open up throughout all of Gazprom's divisions. Around 90 per cent of the graduates of the Tekhnikum later become Gazprom employees. The two principal Gazprom divisions in Novy Urengoy, Gazprom dobycha Urengoy and Gazprom dobycha Yamburg, contribute most to the budget of the institution, providing the programmes with the latest technology. Parents pay onethird of the tuition fee, Gazprom the rest. Much as in Kirovsk, students can learn the entire process of gas extraction in practice-oriented classes and laboratories, and they spend approximately one year on Gazprom's production site as interns, during which they receive a salary (fieldwork conversation with Director Sergei Yalov, Gazprom Tekhnikum, 23 May 2019).

During our focus group meeting, students presented a balanced view of the city as a place for young people. On the "plus" side were statements such as "in Gazprom there are a lot of different directions for work. That's cool. And we have no trouble getting a job where we spent our internships." "The city develops here well; there is a lot to do here, fun." "It's cool to participate in mind sports (intellektual'nye igry), and there are many on offer. And we have a lot of sports facilities here, which is great." On the other hand, the "minuses" sounded like this: "the winter, the darkness, the mosquitoes, the high rate of chronic diseases and heart diseases here". "We need more cultural events, arts, creative arts, youth entertainment. In winter we all sit at home. We should have covered spaces where we can meet." "The new shopping centre is not the best place to hang out: there are drug addicts there, and violence." On the other hand, in a focus group discussion, secondary school 
graduates highlighted that the city is attractive after school only for those with an interest in the gas industry (focus group discussions in the Tekhnikum, 23 May 2019, and in a secondary school, 22 May 2019).

In Neryungri, Yakutugol' has a centre where they train students in almost 200 professions that are in demand at industrial enterprises. For many years the company has also accepted students from the South Yakutian College of Technology as well as from the Training Centre of the city of Neryungri as interns. Many of them later become employees of the company. Thus, the company helps implement what is called a dual training model, where students get training in college as well as in the company. Both parties try to bring training programmes in the colleges as close as possible to real production conditions. In some professions, students get as much as 50 to 70 per cent of their training at the enterprise, with the acquisition of practical skills directly in workplaces through mentoring.

Since 2004, Kolmar, another coal mining company, has managed to compete with the main coal mining company Yakutugol' and to offer a viable alternative as an employer. During fieldwork, both companies competed for the best young specialists. Kolmar had put up posters in the city advertising themselves as an employer, even offering a financial reward for young people who recommend their friends as potential young specialists. Companies competing for the best youth in town is a good sign of city development. Clearly, demand for qualified labour in Neryungri exceeds supply. Companies try to position themselves as attractive employers and offer a variety of benefits in addition to municipal support. For example, Kolmar is investing in a new suburb for the company's workers that aims to host 2100 young families, with "young" being "under the age of 25" (Meeting with company chief of staff department, 30 July 2018). A specially built school, kindergarten, playgrounds, and healthcare centre show their focus on young workers' social wellbeing (MK Yakutia 2020). Both coal companies, Yakutugol' and Kolmar, are also involved in higher education in Neryungri's technical institute. They contribute to training engineers, help equip laboratories and try to make contacts with the best students through work practice even before their graduation in order to recruit them as employees later.

In the focus group meeting with young staff at Kolmar, the young chief of staff explained why they compete for the best young locals: "For the company, young people are a good deal because they are cheap, and you can teach them what is needed." As in Novy Urengoy, the young people themselves had mixed feelings about life in the city. One statement by a very young mother summarized it philosophically: "We always think it's great where we are not. You just have to want it, then you can do many things here." Her colleague left Neryungri immediately after school and came back recently: "Until you finish school it's great here. But 10 years ago it was much worse than now; there is lots to do if you have money." Her colleague specifies what that means:

I want to become a mother here; it's safe and everything here is available close-by: schools, kindergartens, social services. And we have a long 
holiday: every two years our company pays for our holiday travel in full. Also, children can go to camps at company expense; in 2018, 90 children over the age of fourteen were financed. And, our big plus is nature; that is great in summer. But summer lasts only two months. There is energy in this vastness. During winter, it's running home and to work.

This shows that in our case cities there is strong involvement of industry in education and companies engage extensively in measures, making the place attractive for young people to pursue a career in the fields that the companies represent. Fieldwork conversations with young people from within the industry-dominated system reveal the positive sides of this company engagement. The other side of the coin is that apart from industry there is not much else in the way of a career path for a young person in our case cities - the focus of Bolotova's chapter in this volume.

\section{Discussion}

Analysing the implementation of youth policy in mining cities of the Russian Arctic may lead to the conclusion that at the end of the day it is money that matters: the city of Novy Urengoy has the richest industrial company in town and invests a billion rubles in a youth programme, and it is the only town in our comparison with an increase in population. However, it is not yet possible to evaluate the effectiveness of such investments in the long term. Especially in Novy Urengoy, the youngest of the Russian cities in our study, the psychology of transience still creates an image of the city as a place to live in while one works, but not necessarily a place to put down roots. In our fieldwork, it became clear that even in the gas industry, students may plan to "work for a couple years in town, and then leave to the south" (student at Gazprom Tekhnikum, 21 May 2019). This shows that establishing a feeling of a place being "a small homeland" is a difficult task for the future.

In Kirovsk, with its longer history, more young people perceive their city as their permanent home: they may or may not choose to leave it later in life, but not because the place offers a work-only environment. Especially with the city and the company investing in the downhill skiing resort, Kirovsk is slowly starting to develop into a tourist destination, which can become an important factor for economic diversification. Already now this has made the place attractive for entrepreneurs offering low-priced hotel and hostel accommodation, and the ski resort figures prominently in the Russian social media as a hype destination for free-riding (off-piste downhill skiing). A diversified economy may also mean a wider range of options for young people in the community. Establishing hospitality as a field of post-secondary education in Kirovsk in 2018 might contribute to diversification beyond mining.

This observation compares interestingly with observations made by Komu and Adams (this volume) in their case study of the Finnish town of Kolari, where tourism brings more diversity to the town and is a source of employment, while mining is what Haikola and Anshelm (2017) have called a 
"horizon of expectation". However, in Kolari much of the work in tourism is seasonal and done by workers from the south, who leave once the downhill skiing season is over. Komu and Adams show that such employment is not exactly a dream career for young people. Nonetheless, tourism has the potential to attract youth, because of successful locally run tourism businesses. In this respect, Kirovsk presents a very different case, because the principal investor in tourism is the mining company (see Bolotova, this volume), which also sponsors tourism education. In Kolari, the mining company has made no investment at all in tourism. Rather, Komu (2019) shows that tourism benefits from the infrastructure that was built earlier for the mining industry. Nonetheless, in current discussions about mining and tourism as prospective work, many in Kolari perceive mining as a threat to tourism rather than an opportunity, while in Kirovsk it is the mining company that is the driving force behind the tourism. Thus, the role of the company is clearly more important in Russia than in Finland. We speculate that this may be due to the prominent role of the state in the Finnish system, whereby it provides much more for its citizens' basic and extended needs, their wellbeing and their welfare than in Russia. This being the case, in Russia there is greater need and more space for corporate responsibility. On the other hand, Panapanaan et al. (2003, p. 143) have argued that in Finland companies have revived CSR, and education is a key element in their efforts.

The literature (Dushkova and Krasovskaya 2018 and Bolotova, this volume) and first fieldwork experiences suggest that, in addition to big corporate actors, the young civil society in Kirovsk, one independent of the company and the municipal administration, is the most developed of our three case sites.

Across all cities, young adults achieving economic independence from parents and relatives is an important basic condition of wellbeing. For this to happen, the connection between getting a good education, a decently paid profession and opportunities for subsequent employment is crucial, as is access to comfortable housing for young families.

Due to budgetary constraints and the way the Russian tax system is built, the municipalities often have little room for manoeuvre due to insufficient financial resources. Therefore, various forms of public-private co-financing, such as those outlined above, are crucial for creating the conditions that make single-industry towns attractive to youth for planning their future there. In the same vein, the principal industrial companies in the cities operate assistance programmes for young employees to qualify for bank loans or mortgages.

One could argue that company involvement in youth issues compensates at least partially for the lack of state funding. However, unlike in the Soviet Union, companies withdraw their social involvement and argue that their main social task is paying taxes (fieldwork conversation, Yakutugol', Neryungri 1 August 2018). This is similar in international practice, as for example our fieldwork in Tysfjord (Norway) has shown. There, Heidelberg Cement argues that the Norwegian state takes care of social issues 
sufficiently, with the company doing its part in the form of taxes and, occasionally, in-kind contributions (fieldwork Ivanova and Stammler, 21 May 2016, interview with Norcem plant manager). The difference is, however, that Western welfare states provide social services to their populations on a high level, whereas in the Russian context in many cases the services only satisfy basic needs, and industries are the only institutions that can augment these. The level of such needs is formulated in Finland, for example, by the Youth Act. Among other things, we have shown in this chapter that the lack of such a cohesive legal instrument leads to stark differences in services, programmes and infrastructure for youth in different Russian Arctic regions.

However, our fieldwork shows that young people will not be satisfied with mere financial benefits. They want to have not only interesting and well-paid jobs, but also a range of other affordances: comfortable living in extreme climatic conditions, suitable housing; a decent standard of education, healthcare, communications and the Internet; functioning transport infrastructure; cultural facilities; and opportunities for realizing their life plans, having a rewarding social life and raising their children. Based on our analysis of diverse legal acts and programmes which are not connected under a general umbrella, we suggest that better coordination of legislation concerning the Arctic and youth could facilitate development towards providing the opportunities enumerated above. Correspondingly, legal norms governing how to attract youth to and encourage them to stay in the Russian Arctic, which are today scattered in diverse regulatory legal acts, should become an integral part of a unified state youth strategy.

In an effort to this end, the youth chambers established under the parliaments of the Arctic regions of the Russian Federation have set out to convince lawmakers to create conditions for the widest possible inclusion of young people in the development of Arctic education, design, innovation and production. This is most urgent in the case of projects related to the infrastructural development of the North and the Arctic.

\section{Conclusion}

This chapter on youth in the Russian Arctic has outlined the interface between Russia's federal policy and legislation in the sphere of Arctic youth issues and the local outcome of their operation in three case regions. With the strategic importance of the Arctic for Russia's economy, the starting point was the demand for labour in the Russian Arctic extractive industries, juxtaposed with the tendency of young people to migrate from the singleindustry towns studied. Current Russian federal law in the case of both Arctic issues and youth lacks coordination and is fragmented across numerous legislative documents. As such, it does not tackle the problem of youth outmigration from Arctic cities and the demand for qualified youth there in a satisfactory way. Our fieldwork in all three cities with students and educational institutions has shown that training youth to meet such demand is now, to a considerable extent, in the hands of corporate actors instead of 
being regulated by state legislation. In the absence of federal laws on the Arctic and youth, the Arctic regions can make use of their legislative competences and implement their own policies. We have shown through fieldwork evidence that people and decision-makers in the Russian Arctic have more agency than the image of a strong centralised federal state with a strong president may suggest. Moreover, implementation of current federal youth law in the regions is sometimes fragmentary because of a lack of funding. Some of the laws on the books can therefore be seen as little more than declarations of noble aims.

Our analyses have shown a focus of youth legislation on qualifying personnel for working in extractive industries. Considering UN Sustainable Development Goal 11 on cities as an inclusive, safe. resilient and sustainable space for life, this is too narrow a view. If one wants the Arctic to be a home instead of a place to work, more has to be done to increasing the wellbeing of youth beyond the workplace.

We have analysed how youth policy actors on the city level have approached this topic. In Neryungri, the competition for the best young workers in the two coal mining companies creates an atmosphere of development in town that has the potential to pull along both youth and the municipality. Civil society initiatives and citizen participation in shaping their hometown complement that atmosphere. However, young people still lack choices for their life trajectories in town other than working for industry. In Novy Urengoy the situation is similar, but more so than in Neryungri youth grow up with the feeling of their hometown as being a place to leave, even after starting a career in the gas industry. The municipal programme on developing civil society with money from gas industry taxes aims to overcome that transience, but it may well be that money cannot buy sense of place. The example of Kirovsk has shown that more youth initiative was observable with much less money, but a longer history (also see Bolotova, this volume). Additionally, the promising local identity slogan launched by regional authorities, "the North is for living", might have been embraced by young people to the extent that it strengthens their wish to build a future in Kirovsk.

In all of our case sites we have identified promising initiatives to strengthen civil society and collective agency among young people, agency that creates conditions allowing them to shape their hometowns into the kind of sustainable city communities that they would like to live in. Young people have expressed views on what should change in their cities for the better, and they have opportunities to influence this with their own grassroots initiatives, as our analysis and other chapters in this book show. Their involvement in legal initiatives through youth parliaments can contribute to these developments being backed up by state policies, possibly leading towards better, consolidated youth legislation. However, in the current conditions, marked by rather fragmented state involvement in the Arctic of Russia, it is crucial that industry lives up to its social responsibility and contributes financially not only to educating its future employees, but also to making the cities comfortable spaces in which to thrive. 


\section{References}

Adams, R.-M., Allemann, L. and Tynkkynen, V.-P. (this volume) 'Youth well-being in "atomic towns": The cases of Polyarnye Zori and Pyhäjoki', in Stammler, F. and Toivanen, R. (eds) Young people, wellbeing and placemaking in the Arctic. London: Routledge, pp. 222-240.

Administratsiia goroda Novyi Urengoi (2017) $O$ vnesenii izmeneniia v postanovlenie Administratsii goroda Novyi Urengoi ot 01.11.2016 № 366. Available at: http://www. newurengoy.ru/docs/11806-o-vnesenii-izmeneniya-v-postanovlenie-administraciigoroda-novyy-urengoy-ot-01112013-366.html (Accessed: September 26 2019).

Administratsiia Neriungrinskogo Raiona (2016) Ob utverzhdenii munitsipal'noi programmy «Realizatsiia munitsipal'noi molodezhnoi politiki v Neriungrinskom raione na 2017-2021 gody. Available at: http://www.neruadmin.ru/elib/aktOMS/normprav/ 2018/1225_21.08.2018N.pdf (Accessed: September 26 2019).

Administratsiia Neriungrinskogo Raiona (2018a) O vnesenii izmenenii vmunitsipal'nuiu programmu "Obespechenie zhil'em molodykh semei Neriungrinskogo raiona na 2017-2021 goda. Available at: http://www.neruadmin.ru/elib/aktOMS/normprav/ 2018/1620_07.11.2018N.pdf (Accessed: September 27 2019).

Administratsiia Neriungrinskogo Raiona (2018b) O vnesenii izmenenii v prilozhenie $k$ postanovleniiu Neriungrinskoi administratsii ot 14.12.2016 № 1805 «Ob utverzhdenii Poriadka okazaniia dopolnitel'nykh mer sotsial'noi podderzhki obuchaiushchimsia $i$ studentam iz maloobespechennykh semei. Available at: http://www.neruadmin.ru/ elib/aktOMS/normprav/2018/91_25.01.2018n.pdf (Accessed: September 27 2019).

Administratsiia Neriungrinskogo Raiona (2018c) Ob utverzhdenii munitsipal'noi programmy «Realizatsiia otdel'nykh napravlenii sotsial'noi politiki v Neriungrinskom raione na 2017-2021 gody. Available at: http://www.neruadmin.ru/elib/aktOMS/ normprav/2018/1235_24.08.2018\%20N.pdf (Accessed: September 28 2019).

Assotsiatsiia Poliarnikov, R. (2018) Rezoliutsiia-2018. St Petersburg: Forumarctic, 120pp. Available at: http://www.forumarctic.com/upload/conf2018/resolution/arctic_2018.pdf (Accessed: July 23 2019).

Assotsiatsiia Poliarnikov, R. (2019) 'Youth Day for the International Arctic Forum', in Arktika, Nastoiashchee i Budushchee. VII International Arctic Forum. St Petersburg: forumarctica, 5pp. Available at: https://forumarctica.rcfiles.rcmedia.ru/upload/uf/2d c/2dce026b211c2711d9859a7b31934038.pdf (Accessed: December 16 2020).

Bolotova, A. (this volume) 'Leaving or staying? Youth agency and the livability of industrial towns in the Russian Arctic', in Stammler, F. and Toivanen, R. (eds) Young people, wellbeing and placemaking in the Arctic. London: Routledge, pp. 53-76.

Britskaia, T. (2019) ' «Na Severe - zhut'» Gosudarstvo osvaivaet Arktiku iskliuchitel'no s voennymi tseliami. Uroven' zhizni v Zapoliar'e stanovitsia vse nizhe', Novaya Gazeta. 113th edn, 7 October. Available at: https://novayagazeta.ru/ articles/2019/10/07/82266-na-severe-zhut (Accessed: December 10 2020).

Dolgova, A., Ruzakova, V. and Siluanova, L. (2017) Arktika 18-24-35. Vzgliad Molodykh. working group report. Moscow: Tsentr Strategicheskikh Razrabotok, p. 52. Available at: https://strategy.csr.ru/user/pages/researches/Arktika_strategy.pdf (Accessed: December 16 2020).

Dushkova, D. and Krasovskaya, T. (2018) 'Post-Soviet single-industry cities in northern Russia: movement towards sustainable development: A case study of Kirovsk', Belgeo, (4), pp. 1-24. doi: 10.4000/belgeo.27427. 
Federative Council, R. F. (2009) O gosudarstvennykh merakh po privlecheniiu i zakrepleniiu molodezhi vo vnov' osvaivaemykh raionakh Severa i Arktiki. Round table discussion outcome. Moscow: Izd. Soveta Federatsii, p. 3. Available at: http://council. gov.ru/media/files/41d44f243f233576911e.pdf (Accessed: December 16 2020).

Fondahl, G., Espiritu, A. and Ivanova, A. (2020) 'Russia's Arctic Regions and Policies', in Coates, K. and Holroyd, C. (eds) The Palgrave Handbook of Arctic Policy and Politics. London \& New York: Palgrave Macmillan, pp. 195-216. doi: 10.1007/978-3-030-20557-7.

Fondahl, G. et al. (2019) 'Niches of agency: Managing state-region relations through lawin Russia', SpaceandPolity,23(1),pp.49-66.doi:10.1080/13562576.2019.1594752.

Government of the Russian Federation (2014) Osnovy gosudarstvennoi molodezhnoi politiki Rossiiskoi Federatsii na period do 2025 goda. Available at: http://government.ru/docs/15965/ (Accessed: April 25 2020).

Government of the Russian Federation (2016) podprogramma 'Obespechenie zhil'em molodykh semei' federal'noi tselevoi programmy 'Zhilishche' na 2015-2020 gody, Postanovlenie Pravitel'stva RF. Available at: https://rosreestr.gov.ru/upload/Doc/17upr $\%$ D0 $\%$ A2 $\%$ D0 $\%$ B5 $\%$ D0 $\%$ BA $\%$ D $1 \% 81 \%$ D $1 \% 82 \% 20 \%$ D0 $\%$ B $4 \%$ D0 $\%$ BE $\%$ D $0 \% \mathrm{BA} \% \mathrm{D} 1 \% 83 \% \mathrm{D} 0 \% \mathrm{BC} \% \mathrm{D} 0 \% \mathrm{~B} 5 \% \mathrm{D} 0 \% \mathrm{BD} \% \mathrm{D} 1 \% 82 \% \mathrm{D} 0 \% \mathrm{~B} 0$.pdf.

Haikola, S. and Anshelm, J. (2017) 'The making of mining expectations: mining romanticism and historical memory in a neoliberal political landscape', Social \& Cultural Geography, pp. 1-30. doi: 10.1080/14649365.2017.1291987.

Harner, J. (2001) 'Place Identity and Copper Mining in Sonora, Mexico', Annals of the Association of American Geographers, 91(4), pp. 660-680. doi: 10.1111/ 0004-5608.00264.

Heleniak, T. (2009) 'Growth poles and ghost towns in the Russian Far North', in Wilson Rowe, E. (ed) Russia and the North. Ottawa: Univ of Ottawa Press, pp. 129-163.

Hill, F. and Gaddy, C. G. (2003) The Siberian curse: How communist planners left Russia out in the cold. Washington, DC: Brookings Institution Press.

Komu, T. (2019) 'Dreams of treasures and dreams of wilderness - engaging with the beyond-the-rational in extractive industries in northern Fennoscandia', The Polar Journal, 9(1), pp. 113-132. doi: 10.1080/2154896X.2019.1618556.

Komu, T. and Adams, R.-M. (this volume) Not wanting to be "stuck": Exploring the role of mobility for young people's wellbeing in northern Finland', in Stammler, F. and Toivanen, R. (eds) Young people, wellbeing and placemaking in the Arctic. London: Routledge, pp. 32-52.

Konsul'tantPlius, L. information service (2017) Situatsiia: Severnaia nadbavka inostrantsu, Konsul'tantPlius. Available at: https://iak.ru/page.xhtml?u=16A53E80 DC574D75B4C3891FD0FFD025 (Accessed: December 10 2020).

Mikhailovskaia, M. (2018a) 'Kak zainteresovat' molodezh' ostavat'sia v Arktike', Parlamentskaia gazeta, 6 December. Available at: https://www.pnp.ru/social/kakzainteresovat-molodezh-ostavatsya-v-arktike.html (Accessed: July 20 2019).

Mikhailovskaia, M. (2018b) 'Molodezhnyi parlament nauchit pisat' zakony', Parlamentskaia Gazeta, 6 June, p. online. Available at: https://www.pnp.ru/social/ kak-zainteresovat-molodezh-ostavatsya-v-arktike.html

Novosti Murmanska (2020) 'Andrei Chibis rasskazal, kak poiavilsia slogan «Na Severe -zhit'!», Murmanskiy Vestnik, 30 May, p. online. Available at: https://www.mvestnik. $\mathrm{ru} /$ newslent/andrej-chibis-rasskazal-kak-poyavilsya-slogan-na-severe-zhit/

O molodezhnoi politike v Iamalo-Nenetskom avtonomnom okruge (2009). Available at: http://docs.cntd.ru/document/895219346 (Accessed: July 29 2019). 
Ob okhrane sem'i, materinstva, ottsovstva i detstva (2008). Available at: http://docs. cntd.ru/document/819089973 (Accessed: August 4 2019).

Panapanaan, V. M. et al. (2003) 'Roadmapping corporate social responsibility in Finnish companies', Journal of Business Ethics, 44(2), pp. 133-148. doi: 10.1023/ A:1023391530903.

Parente, G., Shiklomanov, N. and Streletskiy, D. (2012) 'Living in the new North: Migration to and from Russian Arctic cities', Focus on Geography, 55, pp. 77-89. doi: 10.1111/j.1949-8535.2012.00048.x.

Pavlov, S. S. (2018) 'Interview with the director of the Neryungri Institute of Technology'.

Press-sluzhba Il Tumena (2019) Narodnye deputaty Iakutii utverdili Polozhenie o Molodezhnom parlamente pri Il Tumene, Ministry of Youth Affairs and Social Communications of the Republic of Sakha (Yakutia). Available at: https://minmol. sakha.gov.ru/news/front/view/id/2980060 (Accessed: December 10 2020).

Proshchalgin, A. (2018) 'Interview with the evangelical youth pastor'. Available at: Neryungri.

Reimer, O. (2019) 'Interview with the Chief of Youth Administration of Novy Urengoy'. Available at: Novy Urenogy.

Romanenko, K. (2019) Predpriiatie vse reshaet: kak ustroeno obrazovanie v monogorodakh, theoryandpractice.ru. Available at: https://theoryandpractice.ru/posts/17240predpriyatie-vse-reshaet-kak-ustroeno-obrazovanie-v-monogorodakh (Accessed: December 16 2020).

Rosstat (2020) 'Chislennost' naseleniia Rossiiskoi Federatsii po Munitsipal'nym Obrazovaniiam'. Statistics Russia. Available at: https://web.archive.org/ web/20200822004543/https://rosstat.gov.ru/storage/mediabank/CcG8qBhP/mun_ obr2020.rar (Accessed: December 16 2020).

Russian Federation, S. D. (2019) Ob obshchikh printsipakh organizatsii mestnogo samoupravleniia $v$ Rossiiskoi Federatsii. Available at: http://www.consultant.ru/ document/cons_doc_LAW_44571 (Accessed: September 24 2019).

Russian Federation, S. D. (2020) O gosudarstvennoi podderzhke predprinimatel'skoi deiatel'nosti v Arkticheskoi zone Rossiiskoi Federatsii. Available at: https://rg.ru/ 2020/07/16/193-fz-ob-arkticheskoy-zone-dok.html (Accessed: December 31 2020).

Severpost, M. (2017) V Murmanskoi oblasti reshili vossozdat' molodezhnyi parlament, severpost.ru. Available at: https://severpost.ru/read/55634/ (Accessed: December 10 2020).

Simakova, A., Pitukhina, M. and Ivanova, A. (this volume) Motives for migrating among youth in Russian Arctic industrial towns', in Stammler, F. and Toivanen, R. (eds) Young people, wellbeing and placemaking in the Arctic. London: Routledge, pp. 17-31.

Stammler, F. (2010) 'The city became the homeland for its inhabitants, but nobody is planning to die here - Anthropological reflections on human communities in the Northern city', in Stammler, F. and Eilmsteiner-Saxinger, G. (eds) Biography, shiftlabour and socialisation in a northern industrial city - the far north: Particularities of labour and human socialisation: proceedings of the international conference in Novy Urengoy, Russia, 4th-6th December 2008. Rovaniemi: University of Lapland, Arctic Centre, pp. 33-43. Available at: http://lauda.ulapland.fi/handle/10024/59445 (Accessed: September 8 2017).

Stammler, F. and Ivanova, A. (2016) 'Resources, rights and communities: Extractive mega-projects and local people in the Russian Arctic', Europe-Asia Studies, 68(7), pp. 1220-1244. doi: 10.1080/09668136.2016.1222605. 
State archive Murmansk (2012) Iz istorii razvitiia zakonodatel'stva o "severnykh l'gotakh». archival resources summaries. Murmansk: Gosudarstvennyi archiv Murmanskoi Oblasti. Available at: https://www.murmanarchiv.ru/index.php/ news/34-publications/327--1-r (Accessed: January 3 2021).

Truntseva, L. (2018) 'Oplata truda. Razbiraemsia v nadbavkakh', Gudok.ru Russian Railroad newspaper. 102nd edn, 21 June, p. 1 http://gudok.ru/zdr/171/?ID=1423506 (Accessed: December 10 2020).

Trutnev, I. and Kozlov, A. (2020) Press-konferentsiia Iuriia Trutneva i Aleksandra Kozlova na temu «Razvitie Arkticheskoi zony Rossiiskoi Federatsii: novye preferentsii dlia biznesa». Available at: https://minvr.gov.ru/press-center/news/26952/ (Accessed: January 1 2021).

Il Tumen (2018) O privlechenii molodykh spetsialistov na gosudarstvennye unitarnye predpriiatiia $i$ v gosudarstvennye uchrezhdeniia Respubliki Sakha (Iakutiia), khoziaistvennye obshchestva. Available at: http://docs.cntd.ru/document/550103122 (Accessed: April 4 2019).

Volgin, N. A., Shirokova, L. N. and Mosina, L. L. (2018) 'Aktual'nye voprosy razvitiia rossiiskogo Severa: kompensatsionnye i stimuliruiushchie sistemy, napravlennye na privlechenie i zakreplenie naseleniia v severnykh i arkticheskikhb regionakh', Uroven' zhizni naseleniia regionov Rossii, 208(2), p. 46.

Vorobiev, A. S. (2019) 'Interview with the coordinator of the youth centre "Nord". Available at: Novy Urengoy.

MK Yakutia (2020) 'V Neriungri nachalos' stroitel'stvo novogo kvartala', $M K$ Yakutia, 10 September, p. online. Available at: https://yakutia.mk.ru/ politics/2020/09/10/v-g-neryungri-nachalos-stroitelstvo-novogo-kvartala.html

Zakonodatel'noe Sobranie YNAO (2016) Molodezhnyi parlament pri Zakonodatel'nom Sobranii Iamalo-Nenetskogo avtonomnogo okruga, Legislative Assembly of the Yamalo-Nenets Autonomous Okrug. Available at: https://zs.yanao.ru/about/collegiate/176/ (Accessed: December 10 2020).

Zamiatina, N. Y. (2020) Gorodskaia Arktika: prostranstva v snegu i doma na merzlote, Go Arctic. Available at: http://goarctic.ru/society/gorodskaya-arktika-prostranstvav-snegu-i-doma-na-merzlote/ (Accessed: December 11 2020). 